\title{
The Effect of Audit Quality and Earnings Management on Firm Performance
}

\author{
$1^{\text {st }}$ Nanik Lestari \\ Accounting Program Study \\ Politeknik Negeri Batam \\ Batam, Indonesia \\ nanik@polibatam.ac.id
}

\author{
$2^{\text {nd }}$ Nur Aeni \\ Managerial Accounting Program Study \\ Politeknik Negeri Batam \\ Batam, Indonesia \\ nur.neni20@gmail.com
}

\begin{abstract}
This study aims to examine the effects of audit quality on earnings management, audit quality and earnings management impact on the performance of nonfinancial companies listed in Indonesia Stock Exchange (IDX) period 2010-2015. Audit quality is proxy by auditor size, audit tenure and audit fees. The earnings management of discretionary accruals used modified Jones models by Dechow (1995), firm performance is proxy by Tobins' $Q$. The analysis technique used is the data panel regression analysis with EVIEWS software. The results of the study found are: firstly, that audit quality has no effect on firm performance, quality audit but has no effect on earnings management and earnings management has no effect on firm performance.
\end{abstract}

Keywords: audit quality, earnings management, firm performance.

\section{INTRODUCTION}

The financial statements as a platform to convey the company's financial information, and as a form of accountability for what has been done by the management on a accounting period. According to the Financial Accounting Standards (2012) issued by Indonesian Accountants Association, the purpose of financial statements is to provide information regarding the financial position, firm performance, as well as changes in the financial position that will benefit a large number of users in making economic decisions. Profit information contained in the statements of income are an important component, because it can describe the performance of the company in good or bad condition, so as to show the level of success of a company.

Management tends to perform earnings management in preparing financial reports, these reports in accordance with the wishes and attract the attention of users of financial statements. One way that is often used is used in a measure of earnings management is to use a proxy Discretionery Accrual. Accrual earnings management has no direct influence on the flow of cash flows, but related to the accrual policies such as changes of accounting method and period costs and income shifting.
Management actions to perform earnings management would reduce the reliability of reported earnings (Scott, 2009). Therefore, it needs public accountant as other parties that can provide the reliability of financial reports statements which have been made the manager through the audit process. Ardiati (2005) states that a high-quality audit act as an effective deterrent earnings management, because management reputation will be ruined if this false reporting detected and exposed.

The empirical evidence regarding the effect of audit quality on earnings management have varying results. Alzoubi (2016) examined the effect of audit quality on earnings management, the study showed that the quality audit negatively affect earnings management activities using proxy Discretionary Accrual (DA). Research on the effect of audit quality on earnings management has been studied previously by Indriani (2010) in Indonesia. The results of these studies concluded that audit quality has positive influence on earnings management activities. Previous results differ from studies conducted by Lidiawati et al (2016) who found that audit quality has no effect on earnings management.

In addition to the earnings management, audit quality factors also affect the performance of the company. Use of high-quality audit services can provide more confidence to investors to invest their capital into the company. The more quality of an auditor will enhance the credibility of the financial statements are expected to affect the company's improved performance.

Results of previous studies regarding the quality of the audit on the performance of companies, among others: first, Farouk and Hassan (2014) concluded that the quality of auditors as measured using the competence and independence of auditors have a significant influence on the financial performance of the company. Second, the study was conducted by Ardiana (2014), results showed that audit tenure negatively affect the value of the company. Third, sayyar et al (2015) concluded that the quality of audits by proxy audit fee and audit firm rotation does not significantly affect the performance of the company

This study, investigation of influence audit quality and earnings management on firm performance, which is the development of the two studies is research Alzoubi (2016) 
who studied the effect of audit quality on earnings management and research Farouk and Hassan (2014) on the effect of audit quality on the financial performance of the company. Differences of this study with previous research is located on the addition of variables used are the first, the company's performance dependent variable using proxies Tobin's Q, based on research conducted by Huang et al (2009). The second addition of quality audit variable is an audit tenure which refers to research conducted by Dinuka and Zulaikha (2014). In addition, this study also establishes earnings management variables as dependent and independent variables.

Based on the background of the above problems, the formulation of the problem in this research are: First, How the effect of audit quality on earnings management. Second, How the effect of audit quality on firm performance. Third How the effect of earnings management on firm performance.

\section{LITERATURE STUDY AND HYPOTHESIS DEVELOPMENT}

\section{Efficient Market Hypothesis Theory, Signal Theory}

The theory of the efficient market hypothesis was first introduced by Fama (1970), this theory is very famous and important part in discussing the theory of corporate finance. The concept of this theory explains that the available information can quickly affect the market contained in the security price changes. But it is difficult to predict when the company will announce new developments.

The second theory is the theory put forward by Spence Signals (1973), said that by giving a signal, the owner of the information seeks to provide information that can be used by the recipient of the information. The manager (agent)as the manager of the company is obliged to give a signal to shareholders(principals) to provide quality information or the value of the company directly via the disclosures in the financial statements. This is because the agent has more information than the principal parties.

\section{Theory Agency (Agency Theory) and Positive Accounting Theory (Positive Accounting Theory)}

Agency theory explains the differences in interests and information between principal and agent, which provides an opportunity for the agent to perform earnings management (Jensen and Meckling, 1976). The agency theory arose because of a contract that occurs between the principal and the other party (the agent) to manage the company and give the authority to the agent in decision-making.

This theory explains the problems that arise from accounting policy, so the company should be able to choose the most appropriate accounting policies to certain conditions in the future. With the freedom in selecting accounting policies, then the manager has a tendency to Opportunistic Behavior (Scott, 2009).

Earnings management is a way of presenting the income statement are adjusted to the desired destination by the manager through the selection of an accounting policy or through management accrual (Scott, 2009). From this sense, the company can conclude that earnings management include managers attempt to maximize profits or minimize accordance with the wishes of the manager. Earnings management activities can be classified into two categories: Real Earnings Management and Accrual Earnings Management. Real earnings management can be done through the accrual transactions affecting cash flow directly, while Accrual earnings management does not directly affect cash flow, but through a change in the method - the method of accounting.

Audit quality is defined as a combination of the probability of an auditor's ability to find a breach in the client's financial reporting and report the violation (DeAngelo, 1981). For users of financial statements, audit of good quality can provide the appropriate opinion and responsible and gave the assurance that there is no fraud or material misstatement. Companies can use a CPA to improve the confidence of external parties to information issued by the management.

\section{The Effect of audit quality on earnings management}

The company is in need of high-quality audits to detect material misstatements in the financial statements. The determines the quality of the audit is the Audit Tenure or length of the assignment of auditors in a company. The longer the auditor in charge in a company could cause significant emotional relationship with the client, resulting in reducedowned and auditor independence will tend to side with the agent. Emotional relationship will lead to asymmetry of information between the agent and the principal, but it also increases profit manajamen practices performed by the agent.

The study was conducted by Dinuka and Zulaikha (2014) which states that the audit tenure has a positive effect on earnings management. Different studies conducted by Inaam and Khmoussi (2012) who found that audit tenure has no effect on earnings management. Based on these arguments, the following hypothesis:

\section{$\mathrm{H}_{1}$ : Audit tenure effect on earnings management.}

\section{The Effect of Audit Quality on Firm Performance}

Credibility of the financial statements can be viewed on the quality audit. The more the credibility of the report, the better the quality of financial reports are generated and delivered to the user reports. Companies that use the services of the big four auditors have experience and reputation have been considered either by the public so that they will be more careful in conducting the audit, so that it can provide better information to users of financial statements and will improve the performance of the company Number of academics and practitioners argue that the longer the auditor in charge in a company are feared to the cooperation because of the close relationship between the auditor and the client. This emotional connection will give a negative perception by the report mainly stockholders that will affect the performance of the company, because they expect the auditors to ensure the accuracy of the statements that have been audited. 
The study was conducted by Ardiana (2014) which states that the audit tenure negatively affect the company's performance. Different studies conducted by sayyer et al (2015) who found that audit tenure has no effect on earnings management. Based on these arguments, the following hypothesis:

H2: Audit tenure effect on the firm performance.

\section{RESEARCH METHODS}

This study uses a quantitative method approach to collecting and analyzing data of financial statements of listed companies in Indonesia Stock Exchange (IDX) during 2010 2015. In this study the variables used is audit quality, earnings management and earnings performance using a proxy Discretionery perusahaan.Manajemen Accrual. This study also uses four control variables are firm size (size), the level of debt (leverage), the rate of growth (Growth) and profitability (Profitability).

The dependent variable used in this study are two Earnings Management and Corporate Performance.Earnings management as measured by proxy Discretionery Accrual. According to DeAngelo (1986) concept of capital accrual has two components, namely discretionary accrual and nondiscretionary accruals. Discretionary Accrual (DA) are accruals that can be controlled by company management. Non Discretionary Accruals (NDA) is accrued based on economic conditions that can not be controlled by the management company. Measurement of earnings management model with modified Jones (Dechow et al, 1995) can be calculated as follows:

a. The formula for determining the total value of the accrual approach to cash flow as follows:

$$
\mathrm{TA}_{\mathrm{it}}=\mathrm{NI}_{\mathrm{it}}-\mathrm{CFO}_{\mathrm{it}}
$$

b. Value Total accruals are estimated with OLS regression equation calculated by:

$$
\begin{aligned}
& \mathrm{TA}_{\mathrm{it}} / \mathrm{A}_{\mathrm{it}-1}=\alpha_{1}\left(1 / \mathrm{A}_{\mathrm{it}-1)}+\alpha_{2}\left(\Delta R E V_{\mathrm{it}} / \mathrm{A}_{\mathrm{it}-}\right.\right. \\
& { }_{1}+\alpha_{3}\left(\mathrm{PPET} / \mathrm{A}_{\mathrm{it}}-1\right)+\varepsilon_{\mathrm{it}}
\end{aligned}
$$

$$
\mathrm{NDA}_{\mathrm{it}}=\alpha_{1}\left(1 / \mathrm{A}_{\mathrm{it}}{ }^{-1}\right)+\alpha_{2}\left(\left(\Delta \mathrm{REV} \mathrm{it}_{\mathrm{it}}-\right.\right.
$$$$
\Delta \mathrm{REC}_{\mathrm{it}} / \mathbf{A}_{\mathrm{it}-1)}+\alpha_{3}\left(\mathrm{PPET} / \mathrm{A}_{\mathrm{it}}{ }^{-1}\right)
$$

c. Value of discretionary accruals (DA) can be calculated by the equation:

$$
\mathbf{D A}_{\mathrm{it}}=\left(\mathrm{TA}_{\mathrm{it}} / \mathbf{A}_{\mathrm{it}-1}\right)-\mathbf{N D A}_{\mathrm{it}}
$$

Description:

TAit $=$ Total accruals for firm $\mathrm{i}$ in period $\mathrm{t}$

NIIT = Earnings firm $\mathrm{i}$ in period $\mathrm{t}$

CFOit = Cash flow from operations for firm $\mathrm{i}$ in period $\mathrm{t}$

Ait-1 = Total assets of the company $i$ at the end of the year $t-$ $\triangle \mathrm{REVit}=$ Changes in the company's revenue fromi year $\mathrm{t}-1$ to year $\mathrm{t}$

$\triangle$ RECit $=$ Changes in receivables $\mathrm{i}$ of year $\mathrm{t}-1$ to year $\mathrm{t}$

PPEit = Fixed assets (property plant and equipment)

company $\mathrm{i}$ in period $\mathrm{t}$

NDAit $=$ Non-discretionary accruals for firm $\mathrm{i}$ in period $\mathrm{t}$

DAit $=$ discretionary accruals firm $\mathrm{i}$ in period $\mathrm{t}$

cit $\quad=$ Error term

In this study of performance measurement is based on proxies Tobin's $\mathrm{Q}$ in order to know the market value of the company that would reflect the company's profits in the future. The formula used in this study is based on research Huang et al (2009), namely:

Tobin's $\mathbf{Q}_{\mathrm{it}}=\frac{\mathrm{MVE}_{\mathrm{it}}+\mathrm{BVA}_{\mathrm{it}}-\mathrm{BVE}_{\mathrm{it}}}{\mathrm{TA}_{\mathrm{it}}}$

Description:

MVE = closing stock price on the last trading day of the end of the third month after the fiscal year multiplied by the number of shares outstanding.

$\mathrm{BVA}=$ The book value of assets, was taken from the Total

Assets.

$\mathrm{BVE}=$ The book value of equity, is taken from the total

equity.

$\mathrm{TA}=$ Total Assets.

it $=$ For each firm i year $\mathrm{t}$

This variable is independent research audit quality. The proxy for audit quality used is Audit Tenure. Audit tenure is his long-time assignment of an auditor in providing audit services to its clients. This study draws on research conducted by Dinuka and Zulaikha (2014). This study measured the audit tenure by looking at the length of the assignment of an auditor in the company until replaced by a new auditor. Measurement audit tenure is measured using the measure is the total number of years of cooperation between auditors with the auditee company successive seen from the annual report of the company.

Control variables used to control the influence of the independent variable on the dependent variable and can reduce the error rate. The formula used to measure the control variable is based on research from Huang et al (2009) and Gerayli et al (2011). Control variables in this study there are four: first, firm size (Size) is measured using the natural logarithm of total assets. Second, the level of debt (leverage) measured by total debt divided by total assets. Third, the rate of growth (Growth) was measured by means of total outstanding shares multiplied by the stock price divided by equity value. Last level of profitability (Profitability) measured by net income divided by shareholders equity.

The samples were done using purposive sampling method of sampling from a population based on a certain criteria. The criteria - criteria that must be met for a sample of this research are: firstly, Non-financial company listed on the Stock 
Exchange during the period 2010 - 2015 and did not experience any delisting during the study period. Secondly, The Company publishes audited financial statements for the period ending on 31 December. Thirdly, Data on variables of the study should be available in full in the financial statements and The Company publishes financial statements in units of currency. Finally, Having a positive equity value because of negative equity value will refract the company's performance as measured by Tobin's Q.

Data collection techniques used in this research is data collection techniques or documentation records in the database. Researchers must collect and trace the necessary data from the company's annual report can be accessed through the site www.idx.co.id,www.finance.yahoo.com and the official website of each company.

This study uses panel data model is the incorporation of data in cross section and time series. Cross section data is the data collected at the same time from several regions, companies or individuals. While the time series data is data arranged in order of time, such as daily data, monthly, quarterly or yearly. According Widarjono (2009) there are three basic approaches used in estimating the regression model with panel data, namely Common Effect Model, Fixed Effect Model and Random Effect Model. Data processing and model selection in this study using the facilities provided by Microsoft Excel and software E-views.

The initial samples are 514 firms, but exclude banking and financial firms (99 firms), initial public offering (91 firms), negative book value equity ( 21 firms), financial reporting with other rupiah currency (53 firms). We also exclude firms is corporate action 25 firms. The final samples are 225 firms, and give a balance panel of 1350 years end observastions over the 6 years $(2010-2015)$.

\section{RESULT AND DISCUSSION}

\section{A. Descriptive Statistics}

Descriptive statistics based on test results in Table 1, it can be seen that the amount of data used in this study is the 1350 sample data. This study examined the first dependent variable in the form of earnings management as measured by a modified model of Jones (EMJ). Model modified Jones (EMJ) has an average value (mean) of 0.005 .

TABLE I. DESCRIPTIVE STATISTICS

\begin{tabular}{|l|r|r|r|r|}
\hline \multicolumn{1}{|c|}{ Variabel } & Mean & \multicolumn{1}{c|}{ Maximum } & Minimum & Std. Dev \\
\hline EM & 0.005 & 1.456 & -2.697 & 0.101 \\
\hline FP & 1.407 & 19.029 & -1.956 & 1.413 \\
\hline AQ & 3.476 & 7.000 & 1.000 & 1.878 \\
\hline SZ & 28.125 & 33.134 & 23.155 & 1.720 \\
\hline LEV & 0.449 & 0.985 & 0.000 & 0.210 \\
\hline GR & 1.813 & 34.147 & 0.003 & 2.828 \\
\hline PROF & 0.106 & 1.435 & -1.584 & 0.199 \\
\hline Sampel (N) & \multicolumn{5}{|c|}{1350} \\
\hline $\begin{array}{l}\text { Notes: Result Descriptive Statistic Dependen Variable:Earnings } \\
\text { Management (EM) with Earnings Management modified jones. Independen }\end{array}$ \\
$\begin{array}{l}\text { Variable: Quality Audit (QA) with Audit Tenure, and Firm Performance (FP) } \\
\text { with Tobins Q. Contro Variable: Size firms (SZ), Leverage (LEV), Growth } \\
\text { (GR) dan Profitbality (Prof). }\end{array}$ \\
\hline
\end{tabular}

The performance of the company has an average value 1.407 indicates that non-financial companies in Indonesia has an average of good growth prospects. Quality audits proxies with Audit Tenure. Audit tenure has an average value 3.475 means an average of an auditor to audit the company for three years in a row. The size of the company shows average values (mean) 28.124, debt level indicates average values (mean) of corporate debt ratio of 0.449 , or about $44.9 \%$ of total assets, which means the company is still able to cover the debt with assets owned so the ratio is quite reasonable. Growth rate has an average value (mean) 1.813, which means non-financial company growth expectations in Indonesia is very high so it allows the ability to manage earnings. Profitability has an average value (mean) of $10.6 \% 0.106$ or non-financial companies in Indonesia shows the efficiency in the use of capital owned.

\section{B. Classical Assumption Test}

Before performing regression testing to see the influence of the independent variable on the dependent variable, it is necessary to test the classical assumption. Results of testing the classical assumption in this study as follows: Test Multicollinearity and HeteroskidastityTest

Test Multicollinearity Based on table 2 it can be seen that the correlation coefficient between the variable has a value below 0.8 . This indicates that the data in this study do not occur multikolinearitas.

TABLE II. TEST MULTICOLLINEARITY

\begin{tabular}{|c|c|c|c|c|r|}
\hline & AQ & SZ & LEV & GR & \multicolumn{1}{c|}{ PROF } \\
\hline AQ & 1.000 & 0.304 & 0.003 & 0.123 & 0.081 \\
\hline SZ & 0.304 & 1.000 & 0.141 & 0.117 & 0.224 \\
\hline LEV & 0.002 & 0.141 & 1.000 & 0.126 & -0.009 \\
\hline GR & 0.123 & 0.117 & 0.126 & 1.000 & 0.217 \\
\hline PROF & 0.081 & 0.224 & -0.009 & 0.217 & 1.000 \\
\hline
\end{tabular}

HeteroskidastityTest using white test heteroscedasticity. From Table 3 shows that the value of Obs * R-Squared is 3.771 while the probability value is $0.8772>0.05$, we may conclude that the data do not experience the problem of heteroscedasticity.

TABLE III. TEST HETEROSKIDASTITY

\begin{tabular}{llll}
\multicolumn{4}{l}{ Heteroskedasticity Test: White } \\
\hline \hline F-statistic & 0.469557 & Prob. F(8,1341) & 0.8781 \\
Obs*R-squared & 3.771103 & Prob. Chi-Square(8) & 0.8772 \\
Scaled explained SS & 776.9441 & Prob. Chi-Square(8) & 0.0000 \\
\hline \hline & & &
\end{tabular}

\section{The effect of audit quality by audit tenure on earnings management \\ Hypothesis Based on test results showed no influence} between audit tenure on earnings management. This is evidenced by the significant value that indicates a value of 0.859 . Therefore it can be concluded that the hypothesis $1\left(\mathbf{H}_{\mathbf{1}}\right)$ not supported. The results are consistent with research 
harusetya (2012) which states that the audit tenure has no effect on earnings management. This is in contrast to the research conducted by Dinuka and Zulaikha (2014) which states that the audit tenure has a positive effect on earnings management. The longer the period of the assignment is done in the company's accounting firm will not affect the auditor to limit earnings management practices that do corporate managers.

TABLE IV. RESULT REGRESSION THE EFFECT AUDIT QUALITY ON EARNINGS MANAGEMENT

\begin{tabular}{|l|r|r|r|}
\hline Variabel & Coefisien & \multicolumn{1}{|c|}{ t-Stat } & \multicolumn{1}{c|}{ Prob } \\
\hline C & -0.033 & -0.702 & 0.483 \\
\hline AQ $\left(\mathbf{H}_{\mathbf{1}}\right)$ & 0.000 & 0.178 & 0.859 \\
\hline SZ & 0.001 & 0.591 & 0.555 \\
\hline LEV & 0.014 & 1.028 & 0.304 \\
\hline GR & 0.000 & -0.159 & 0.874 \\
\hline PROF & 0.020 & 1.354 & 0.176 \\
\hline R-Squared & & 0.003 \\
\hline Adjusted R-Squared & & -0.001 \\
\hline Prob (F-statistic) & & 0.535 \\
\hline N & & 1350 \\
\hline Hasil Uji & $\begin{array}{c}\text { Common } \\
\text { Effect }\end{array}$ \\
\hline $\begin{array}{l}* \\
* \text { * Signifikan padal level 10\% }\end{array}$ & \\
\hline
\end{tabular}

D. The effect of quality audit by audit tenure on firm performance

Based on the results of hypothesis two $\left(\mathbf{H}_{\mathbf{2}}\right)$ testing shows there is influence between audit tenure on the performance of the company and positive coefficient. This is evidenced by the results of the regression coefficient showed a value of 0.0760 with a significance value of 0.0000 . Therefore it can be concluded that the hypothesis $2\left(\mathbf{H}_{2}\right)$ supported. There is influence between auditor tenure and corporate performance.

TABLE V. RESULT REGRESSION THE EFFECT AUDIT QUALITY ON

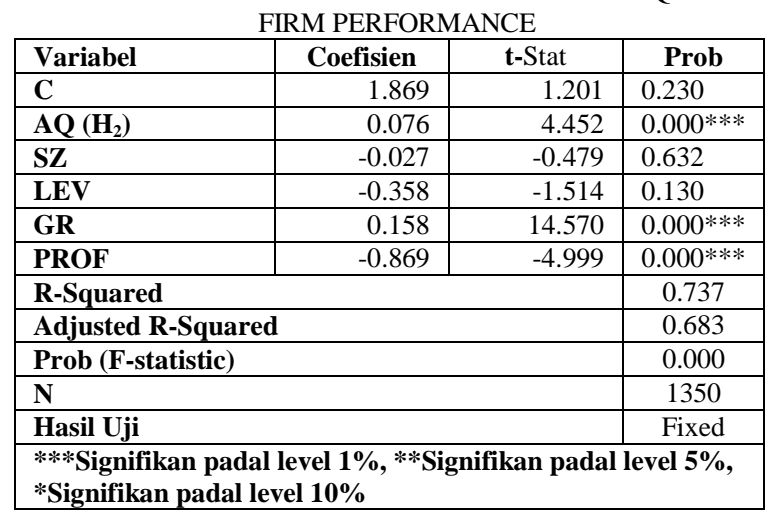

The results of this study differ from research conducted by Sayyar et al (2015) which states that audit firm rotation does not affect the value of the company. The longer the period of the assignment is done in the company KAP auditor will seek to ensure that the company has a good yan performance that cooperation between the auditor and because of the lien can be prolonged. This will have an impact on improving the performance of companies that reflected positive market response.

\section{CONCLUSIONS}

This study aims to provide empirical evidence about the effect of audit quality on earnings management and audit quality influence on corporate performance of companies listed on the Indonesian Stock Exchange (BEI) in the period 2010-2015. Earnings management variables were measured using the modified Jones models. The author can draw conclusions as follows: Firstly, quality audits by audit tenure has no effect on earnings management. auditor assignment period in a short time or a long time did not influence the auditor in detecting earnings management. Secondly, quality audits by audit tenure on the performance of the company, the length of audits will increase the services performed by the auditor, it will have an impact on improving the company's performance is positive.

This study has some limitations that may affect the results of the research, among other things: First, the study was confined to the non-financial companies in the areas listed on the Stock Exchange, so not represent all companies listed on the Stock Exchange. Second, the study period was only six years ie from 2010 - 2015. Third, this study only uses audit tenure proxy of audit quality only. Fourth, a measure of earnings management variable focuses only on accrual earnings management.

Based on research, the advice that can be given is the first, further research is expected to increase the number of samples and the study period. Second, further research can add a proxy or other independent variables that can improve the performance of the company. Third, further research can use real earnings management and accrual in the study.

\section{REFERENCES}

[1] Afriyenti, M. (2009). Pengaruh Accrual Earning Management dan Real Earnings Management terhadap Kinerja Perusahaan dengan struktur kepemilikan sebagai variabel moderasi. Tesis program pasca sarjana (tidak dipublikasikan) Universitas Gadjah Mada. Yogyakarta.

[2] Alzoubi, E. S. (2016). Audit Quality an Earnings Management : Evidence from Jordan. Journal of Applied Accounting Research. Vol.17, Issue. 2, pp.1-18.

[3] Ardiati, A. Y. (2005). Pengaruh Manajemen Laba Terhadap Perusahaan yang diaudit oleh KAP Big 5 dan KAP Non Big. Simposium Nasional Akuntansi VI. Surabaya.

[4] DeAngelo, L. E. (1981). Auditor Size and Audit Quality. Journal of Accounting and Economics, 3(3), pp. 183 - 199.

[5] Dechow, P., Sloan, R., \& Sweeney, A. (1995). Detecting Earnings Management. The Accounting Review 70, pp.193 - 225.

[6] Dewata, E., Riama, L. V., Yulsiati, H., \& Sandrayati. (2015). Pengaruh Board Size dan Kualitas Audit Terhadap Nilai Perusahaan Tambang Batu Bara yang Terdaftar di BEI. Simposium Nasional Akuntansi XVIII, Medan.

[7] Dinuka, V. K., \& Zulaikha. (2014). Analisis Pengaruh Audit Tenure, Ukuran KAP dan Diversifikasi Geografis terhadap Manajemen Laba. Diponegoro Journal of Accounting. Vol.3, No.3, pp. 568 - 668.

[8] Dos Santos, C. A., Cerqueira, A., \& Brandao, E. (2016). Audit Fees, Non-Audit Fees and Corporate Performance. FEP-UP School of 
Economics and Management university of porto.

[9] Fama, E., \& French, K. (1998). Taxes, Financing Decisions, and Firm Value. 53 No. 3 .

[10] Farouk, M. A., \& Hassan, S. U. (2014). Impact of Audit Quality and Financial Performance of Quoted Cement Firms in Nigeria. International Journal of Accounting and Taxation Vol 2, 01-22.

[11] Fitriyani, D., Prasetyo, E., Mirdah, A., \& Putra, W. E. (2014). Pengaruh Manajemen Laba Terhadap Kinerja Perusahaan dengan Kualitas Audit sebagai Variabel Pemoderasi. Jurnal Dinamika Akuntansi vol 6, 133141.

[12] Gerayli, M. S., Yanesari, A. M., \& Ma'atoofi, A. R. (2011). Impact of Audit Quality on Earnings Management : Evidence from Iran. International Research Journal of Finance and Economics, Issue 66.

[13] Herusetya, A. (2012). Analisis Kualitas Audit terhadap Manajemen Laba Akuntansi : Studi Pendekatan Composite Measure Versus Conventional Measure. Jurnal Akuntansi dan Keuangan Indonesia, Vol.9, No.2.

[14] Huang, P. Z. (2009). Do Artificial income smoothing and real income smoothing contribute to firm value equivalenty? Journal of Banking \& Finance.

[15] Inaam, Z., Khmoussi, H., \& Fatma , Z. (2012). Audit Quality and Earnings Management in the Tunisian Context. International Journal of Accounting and Financial Reporting, Vol.2, No.2.

[16] Indonesia, I. A. (2012). Standar Akuntansi Keuangan. Jakarta: IAI

[17] Indriani, Y. (2010). Pengaruh Kualitas Auditor, Corporate Governance, Leverage dan Kinerja Keuangan terhadap Manajemen Laba. Skripsi (tidak dipublikasikan). Universitas Diponegoro.Semarang.

[18] Jensen, M., \& Meckling, W. (1976). Theory of the firm: Managerial behavior, agency costs and owership structure. Journal of Financial Economics Vol. 3 (4), 305-306.

[19] Lidiawati, N., \& Asyik, N. F. (2016). Pengaruh Kualitas Audit, Komite Audit, Kepemilikan Institusional, Ukuran Perusahaan terhadap Manajemen Laba. Jurnal Ilmu dan Riset Akuntansi, Vol.5, No.5.

[20] Nini, \& Trisnawati, E. (2009). Pengaruh Independensi Auditor pada KAP Big Four terhadap Manajemen Laba. Journal Bisnis dan Akuntansi, Vol.11, No.3, pp.175 - 188.

[21] Roodposhti, F. R., Rezaei, B. B., \& Salehi, A. (2012). Analysis of Power and Specification of Accruals - Based Model to Detect Earnings Management. Journal of Basic and Applied Scientific Research. Vol.2 (10), pp.9961 - 9969

[22] Sari, P. R. (2008). Hubungan Komite Audit Terhadap Kinerja Keuangan Melalui Good Corporate Governence Sebagai Variabel Intervening. Universitas Islam Indonesia. Yogyakarta.

[23] Sayyar, H., Basiruddin, R., Rasid, S. A., \& Elhabib, M. A. (2015). The Impact of Audit Quality on Firm Performance: Evidence From Malaysia. Journal of Advanced Review on Scientific Research, 1-19.

[24] Scott, W. R. (2009). Financial Accounting Theory (5th ed.). Prentice Hall: Canada Inc.

[25] Spence, M. (1973). Job Market Signaling . The Quarterly Journal of Economics, 87, (3), pp. 355-374.

[26] Sukesih, \& Risa, N. (2014). Pengaruh Manajemen Laba Terhadap Kinerja Keuangan Perusahaan Melalui GCG Sebagai Variabel Moderating. Jurnal Reviu Akuntansi dan Keuangan Vol 5, 70-84.

[27] Widarjono, A. (2009). Ekonometrika Pengantar dan Aplikasinya edisi Ketiga. Yogyakarta: 